\title{
THE TEACHER'S EMOTIONAL COMPETENCE IN SUBJECT- SUBJECT INTERACTION WITH FUTURE OFFICERS-BORDER GUARDS IN FOREIGN LANGUAGE LEARNING ENVIRONMENT
}

\section{Valentyna Hrishko-Dunaievska}

\section{INTRODUCTION}

Modern social processes, social and political situation create new threats in the national security system, especially in the field of state border protection. This problem is strongly addressed to the State Border Service of Ukraine (SBGSSU) as new tasks and functional responsibilities of border guards emerge in the context of integrated border management.

In order to create a single area of European higher linguistic education, there was a need to reformat the interaction process between the teacher and future officers, where an adequate level of foreign language skills is one of the main professional competence components. The need for highly qualified specialists is growing especially due to the international cooperation between the border agencies of the world countries, the European Union's attention to the border protection problems, international cooperation of Ukraine with law enforcement and security agencies, intensification of participation of the Ukrainian servicemen in joint operations, trafficking in human beings, drugs and weapons, interaction with international organizations representatives. Taking into account Ukraine's cooperation in the framework of the NATO-Ukraine Professional Development Program on military reforms and within the framework of the STANAG 6001 agreement on defining the linguistic competence of military professionals, future officers' foreign language training is of particular importance. This requires a substantial updating of the content and search for the most effective forms and methods of the educational process at higher military educational institutions in order to ensure a sufficient level of cadets' foreign language knowledge, effective interaction in the system «teacher-cadetborderguard» in order to find ways of cooperation in the field of security and defense reformation, competitiveness and integration into the modern world.

We find its effectiveness in the key and regulatory role of the teacher as the subject of the educational process management. Recognition of this position initiates increased researchers' attention in the field of educational psychology to the personality of the teacher of the higher military educational institution in general and his emotional intelligence, emotional 
competence in particular. As the professional activity of the teacher belongs to the «man-man» interaction sphere and is related to the interaction both with the study group as a whole and with interpersonal interaction with the subjects of studying. In view of this, it can be argued that the importance of the emotional competence of such a specialist is essential to ensure the success of his professional activity.

The purpose of the study is to theoretically and empirically investigate the role of teacher's emotional competence in subject-subject interaction with future officers-borderguards in foreign language learning environment.

The object of the study is the joint foreign language learning activity process of a teacher and future officers-borderguards at a higher military educational institution.

The subject of the study is the teacher's emotional competence development in subject-subject interaction with future officers-borderguards in foreign language learning environment.

According to the purpose, object and subject of the study, the main tasks are defined: to analyze the existing conceptual approaches to the study of the problem; to investigate the notion of emotional competence of the foreign language teacher of a higher military educational establishment; to define the psychological features of the teacher and cadets-borderguards' interaction in the joint foreign language learning activity process ; to highlight the results of empirical and experimental results focused on foreign language learning effectiveness at a higher military educational institution.

To solve the problems identified in the study, the following methods have been applied: theoretical methods (the study and analysis of scientific literature, comparison, generalization, systematization of scientific sources to determine the state of development of the research problem; empirical methods - psychological and pedagogical experiment: observation, questioning, testing (Hall test for determining the level of emotional intelligence).

\section{The concept of emotional competence in contemporary psychology}

The study of this phenomenon is a new segment in the personality emotional sphere research. The expediency of studying emotional competence is conditioned by the importance of emotions in one's life and human activity in general ${ }^{1}$ (O. Lazurenko, 1997).

It is widely recognized that emotions are included in all person's mental processes and states; they accompany any manifestations of his activity.

${ }^{1}$ Lazurenko O.O. (1997) Emotsii i yikh znachennia v zhyttiediialnosti liudyny [Emotins and their meaning in person's life activity]. Kyiv. [in Ukrainian]. 
A wide range of emotions indicates significant potential for an emotional factor $^{2}$ (K. Izard, 1980).

Theoretical analysis made it possible to generalize the results of different authors' researches by the level of structure and development of theoretical conceptions of the studied phenomenon. In general, the fundamental theoretical and experimental studies are highlighted in the psychological and pedagogical literature, they relate to the patterns of the emotional sphere formation, general aspects of the problem of emotions, emotional maturity etc.

In the psychological and pedagogical literature the problem of psychological culture of personality is revealed in the works of G. Ball, M. Bastun, I. Ziaziun, O. Ignatovich, V. Panchenko, P. Perepelytsia, E. Pomytkin, V. Rybalki, Z. Stanovsky, N. Chepeleva and others; formation patterns of the emotional sphere, general aspects of the problem of emotions, emotional maturity are grounded in the works of G. Breslav, O. Zaporozhets, O. Kulchytska, A. Olshannikov, A. Sukharev, O. Chebykin, O. Yakovleva and others.), emotional intelligence is studied by R. Bar-On, D. Goleman, D. Caruso, D. Liusin, J. Mayer, P. Salovey and others.

O. Bondarenko, S. Maksimenko, M. Tomchuk, T. Shcherban and other scientists consider the content of the teacher's psychological competence at a higher military educational institution, taking into account the peculiarities of his professional socialization. Some peculiarities of the professional activity of a foreign language teacher in a higher military educational institution are considered in the works of O. Volobuyeva, N. Gotsulyak, O. Grinchyshyn, O. Voityuk and others. However, there are still a lot of open questions regarding the improvement of the teacher's psychological competence, in particular the teacher of a foreign language in the process of subject-subject interaction at a higher military educational institution, regarding the question of his emotional intelligence and emotional competence. First of all, we set out to investigate these issues within the context of subject-subject interaction in the «teacher - future officerborderguard «system in the process of mastering a foreign language.

It is worth noting that the theoretical and methodological approaches to the problem of correlation of the intellectual and the emotional were considered in the works by B. Ananiev, L. Vygotsky, S. Rubinstein, O. Leontiev, V. Myasyshchev, O. Tikhomirov and others. Well-known psychologists V. Viliunas pointed to the close connection of thinking, intelligence and emotional processes. Some of them emphasized that with all the importance of intellectual comprehension and world cognition, emotions

\footnotetext{
${ }^{2}$ Izard K. (1980) Emocii cheloveka [Man's Emotions]. M. [in Russian].
} 
and feelings determine the main line of human behavior (V. Viliunas, B. Dodonov, K. Izard, O. Luk, P. Simonov and others).

Further study of emotions came at the end of the last century, when the concepts of «emotional intelligence» and «emotional competence characterizing the ability to manage emotional phenomena and properties appeared. It has led to an intensive increase in the number of scientific publications aimed at studying these phenomena.

T. $\operatorname{Komar}^{3}$ (T. Komar, 2014, p. 6) states that "people are not only socially but also emotionally and psychologically connected to each other. The quality of human life depends to a great extent on the relationship with other people, on the feelings and cravings felt by man. All this is exacerbated by the fear of loss or circumstances in which these relationships take different forms - from confrontation, remoteness, when only dependence, affinity, trust, and various forms of attachment are associated with another person».

In our time, the growing interest of scientists in the study of human emotions is the emergence of trends in the use of categorical concepts such as emotional thinking, emotional giftedness, emotional creativity, emotional regulation, emotional maturity emotional reasoning ${ }^{4}$ (E. Nosenko, 2000), emotional self-awareness ${ }^{5}$ (O. Vlasova, 2005).

In modern psychological and pedagogical theories emotion is considered as a special type of knowledge ${ }^{6}$ (E. Yakovleva, 1997).

The notion of emotional competence is a later formation than emotional intelligence. The concept of emotional intelligence emerged as a term in the psychological literature with the release of the famous Howard Gardner's monograph «Frames of mind» in 1983. Gardner suggested that there is not one single type of intelligence that influences the success of human life in a

${ }^{3}$ Komar T.V. (2014) Sotsialno-psyhologichnyi prostir yak chynnyk profesiinoii zrilosti osobystosti [Social and psychological space as a factor of personality professional maturity] [Електронний ресурс] Visnyk Natsionalnoi akademii Derzhavnoi prukordonnoi sluzhby Ukrainy - Scientific works collection of National academy of the State Border Guard Service of Ukraine- Issue 2. - Retrieved from: http://nbuv.gov.ua/UJRN/Vnadps_2014_2_17. [in Ukrainian].

${ }^{4}$ Nosenko E. L., Kovryga N. V. (2000) “Emotsiina rozumnist” iak determinant uspishnoi zhyttiediialnosti liudyny I shliahy iioperatsionalizatsii [Emotional reasonability as a factor of successfulperson's life activity and the ways of its operanalization]. Visnyk Dnipropetrovskogo Universytetu [Herald of the Dnipropetrovsk University. - Pedagogy and Psychology. - Issue. 6.

${ }^{5}$ Vlasova O. I. (2005) Psyhologia sotsialnyh zddibnostei: structura, dynamika, chynnyky rozvytky: monografia [Psychology of social abilities: structure, dynamics, development factor: Monograph]. K.: Vydavnycho-poligrafichnyi tsentr "Kyivskyi Universytet". Publishing center "Kyiv University". [in Ukrainian].

${ }^{6}$ Yakovleva E. L. (1997) Emotsionalnyie mehanismy lichnosnogo i tvorcheskogo razvitia [Emotional mechanisms of personal and creative development]. Voprosy psihologii. Psychology Issues. - No 4. [in Russian]. 
certain way, but rather a sufficiently wide range of subtypes of intelligence with seven major variants of these subtypes. His list of subtypes of intelligence included: verbal, logical, mathematical, spatial, kinetic, musical and emotional types of intelligence ${ }^{7}$ (E. Nosenko, n. Kovryga, 2003). The latter was divided by Gardner into two further subtypes: intrapersonal and interpersonal ones. Interpersonal type characterizes a person's ability to interact with other people. Intrapersonal intelligence involves the ability of a person to self-actualize in the life, to motivate oneself for intensive activity in order to achieve success.

In recent years, there have been many publications in which researchers have substantiated a more detailed definition of the concept of emotional intelligence. Mayer and Salovey's research works offer a more detailed interpretation of the components of emotional intelligence, which can be considered as a further development of understanding of the concept of emotional intelligence proposed by psychologist Gardner.

The free encyclopedia Wikipedia presents emotional intelligence as a group of mental abilities involved in the awareness and understanding of person's own emotions and those of other people. People with high level of emotional intelligence have a good understanding of their emotions and feelings of others, can effectively manage their emotional sphere, and therefore in society, their behavior is more adaptive and they achieve their goals in interaction with others more easily.

According to the R. Bar-On's theory, emotional intelligence is defined as a set of diverse abilities that provide the opportunity to act successfully in any situation. The scientist identified 5 subcomponents that characterize the structure of emotional intelligence: self-understanding (awareness of own emotions, self-confidence, self-actualization); communicative potential (empathy, social responsibility); adaptive abilities (ability to overcome difficulties, emotional lability); antistress potential (self-control); optimism.

In Wikipedia a summary table showing the relationship of the structure of emotional intelligence with its functions is provided. The structure contains the following abilities: cognitive (provide interpretive function); emotional abilities (regulatory function); adaptive abilities (adaptive and stress-protective functions); social abilities (activating function,

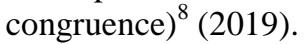

\footnotetext{
${ }^{7}$ Nosenko E. L., Kovryga N.V. (2006) Emotsiinyi intellect: kontseptualizatsia fenomeny, osnovni funktsii : monografia. [Emotional intelligence: phenomenon conceptualization, main functions: monograph]. - Vyshcha shkola. Higher School. [in Ukrainian].

8 Free Encyclopedia (2019). Retrieved from: https://uk.wikipedia.org/wiki/ Емоційний_інтелект.
} 
Today, there is not much research into the phenomenon of emotional competence. These are some works by D. Goleman, P. Salovey, K. Saarney, J. Mayer, M. Reynolds D. Goleman, K. Saarny, G. Breslav, I. Andrieeva, E. Nosenko and others. This problem is actively discussed and developed in the works of G. Garskova, D. Lusina, M. Manojlova and other psychologists. The analysis of the scientific and methodological literature shows that among the researchers of emotional competence there is no unambiguous opinion regarding the definition of this concept, its content, structure, as well as the factors that determine its development.

Recently, researches of Ukrainian scientists on the problems of emotional competence studying, its structure and functions appear: works by I. Arshava, O. Vlasova, S. Derev'yanko, N. Kovryga, E. Lazurenko and others. These researchers view emotional competence as a universal tool for success in all life spheres, and the result of high emotional competence is the ability to manage own emotions and the process where those emotions develop. It significantly expands the problems of research, attracts new thoughts, developments, methods, allows to compare traditional approaches with the latest, to comprehend domestic experience in the context of the world. That is why, in our deep conviction, it will be appropriate to study in detail the the emotional competence content in the frame of subject-subject interaction in the foreign language learning environment at a military educational institution. The problem of emotional intelligence has become quite popular and, therefore, we'd like to take a fresh look at the content of the emotional sphere of the individual as a whole. After all, the problems we are exploring are of great interest in the strategies of organizing and implementing subject-subject interaction in the conditions of mastering a foreign language.

\section{The content of emotional competence in subject-subject interaction in foreign language learning process at a higher military educational institution}

Interaction is characterized as social, group activity, human impact on the individual, as a multilevel phenomenon in which cooperation is distinguished as the highest level of interaction ${ }^{9}$ (A. Leontiev, 2001).

One of the important aspects of interaction is its «psychology», that is, the attitude towards another person. We consider interaction as a process of influence of subjects on each other, characterized by the emergence of connections, interdependence and mediation of their joint activity or

9 Leontiev A. N. (2001) Dieiatelnost. Soznanie. Lichnost. [Activity. Consiuosness. Personality] - M. [in Russian]. 
communication. Interaction takes two forms: communication and joint activity (although their separation is to some extent relative, since joint activity cannot be realized without elements of communication and in turn, communication often acts as a component or means of joint activity), we use the category interaction that reflects processes of communication and collaborative activities as well ${ }^{10}$ (V. Hrishko-Dunaievska, 2017). Communication is the interaction of two or more people, consisting of the information exchange of cognitive or affective-evaluative nature. B. Lomov described the category of communication as the essential aspect of human being - interaction at the level of subject-subject communication ${ }^{11}$ (B. Lomov, 1981).

A number of scientists, examining the psychological problems of interaction between the subjects of the pedagogical process, identified the characteristic features of different parties of communication, emphasizing, in particular, the role of their specific psychological characteristics, especially such characteristics as psychological and pedagogical observation, depth of empathy, accuracy of social perception ${ }^{12}$ (K. Dubovyi, 2012).

The psychologist T. Shcherban in her research reveals the content of such kind of communication, which realizes the ability of the teacher and the student to relationship, as educational communication, substanyiating it as a special kind of relationship between (among) people (which not only transfers knowledge, but also develops the aspirations and skills independently to acquire new knowledge, new experience) as a process of collaboration between the teacher and the student, in which this form of interaction is based on active feedback, which organizes, regulates and enriches each of this process participants ${ }^{13}$ (T. Shcherban, 2004).

The structure of educational communication, from the point of view of the researcher, is characterized by the unity of external, behavioral, operative-active side and internal, deep one, which includes motivational

${ }^{10}$ Hrishko-Dunaievska V. A. (2017) Osobluvosti subiekt-subiektnoi vzaiemodii v protsesi vyvchennia inozemnoi movy $u$ vyshchyh viiskovyh navchalnyh zakladah [Peculiariyies of subject-subjekt interaction in the foreign language learning process at higher military educational institution] (PHD Thesis in "Pedagogic and Age psychology": specialty 19.00.07). Khmelnytskyi. (NASBSU) [in Ukrainian].

${ }^{11}$ Lomov B. F. (1981) Problema obshcheniia v psihologii [Problem of communication in psychology] - M.: Science. [in Russian].

${ }_{12}$ Dubovyi K. V. (2012) Psyhologichni umovu rozvytku komunikatyvnyh $i$ kognityvnyh komponentiv inshomovnyh zdibnostei studentiv [Psychological conditions of development of students' communicative and cognitive foreign language abilities] PHD Thesis in "Pedagogic and Age psychology": specialty 19.00.07. - Khmelnytskyi: NASBGSU publ. [in Ukrainian].

${ }^{13}$ Shcherban T. D. (2004) Psyhologia navchalnogo spilkuvannia: monografia [Psychology of study communication]: monograph. - K.: Millenium. [in Ukrainian]. 
and semantic, value characteristics and emotional and empathic capabilities of the personality and plays a decisive, determinative role.

V. Sukhomlynskyi emphasizes the need to establish such relationships between the teacher and students, which can be characterized as spiritual community, mutual trust, openness, kindness. Therefore, when addressing the teachers, he emphasizes that it is necessary to master the art of empersonation, the art of active emotional and intellectual complicity with the subjects of studying process ${ }^{14}$ (V. Sukhomlynskyi, 1974).

Our study would not be complete without a theoretical analysis of the approaches of scientists to the essence of subject-object and subject-subject interaction. Communication, including pedagogical, implemented on the basis of «subject-object» principles, where only one partner acts in the full role of the subject, while the other partner is assigned the role of a simple object of influence and manipulation. This, in particular, is the communication on the principle of orders, commands, schoolings, etc. The same types include common cases of dominance of one of the partners, asymmetry of the parties to the communication, the desire to assert the priority of one of the interlocutors, ignoring its sovereignty and independence, as well as cases of mistrust and desire to approve a single and 'indisputable' point of view; selfishness and rigidity in communication when for one reason or another communication does not take on the role of genuine dialogue but remains monologous. The emotional aspects of human interaction are also ignored. Another approach ${ }^{15}$ (S. Batrakova, 1986) in the teacher-cadets relationship is characterized as subject-subject connection. In this case, the teacher proceeds from the fact that the student appears or should act as a «living person expressing emotions», a communicating subject. Therefore, within the subject-subject pedagogical communication there is a transfer of positive knowledge, because communication takes place on the interpersonal emotional level, not on the inter-personal level, as in the subject-object style.

According to this model, pedagogy of cooperation, polysubjective approach, personal oriented interaction is developed. In this case, both the teacher and the cadet are recognized as equal subjects of pedagogical interaction. They have a certain freedom in designing their own activity, a characteristic feature of which is the ability to make independent choices, to realize their «I». The main contradictions are solved by cooperation, not by coercion. Relationships are built on a realistic basis of mutual acceptance

${ }^{14}$ Sukhomlynskyi V. A. (1974) Serdtse otdaiu dietiam [Give my heart to the children]. 5-th issue. - K.: Radianska shkola. Soviet Shcool. [in Russian].

${ }^{15}$ Batrakova S. N. (1986) Osnovy professional-pedagogicheskogo obshchenia [Principles of pedagogical communication] - Yaroslavl: Yar. state. university. [in Russian]. 
and understanding, and therefore everyone has the opportunity to be individual. Self-realization of the teacher's personality is a prerequisite for self-realization of the student and vice versa, successful personal growth of the student is an incentive for the development of the teacher's personality ${ }^{16}$ (I. Bulakh, 2002), ${ }^{17}$ (V. Patiushkin, 1984). The emotional component as well is the ability to respond spiritually, which is indisputably important for the subject-subject interaction ${ }^{18}$ ( I. Bekh, 1998, p. 125).

According to psychologist I. Postalovsky ${ }^{19}$ (I. Postalovskyi, 1999, p. 66), "co-operative interaction means that the teacher and the student work together. The fundamental condition for subject-subject interaction is to give the partner the right to choose his or her behavior. And, at the same time, it is necessary to encourage him to share emotions in a pedagogically appropriate direction. Teacher, acting as a mentor, facilitator, initiator of interaction, the result of which depends on whether the student agrees to participate in the collaboration, whether he accepts the offered assistance or make the appropriate choice.

We can state that all conceptual approaches to determining the subjectsubject interaction of the educational process indicate the presence and importance of the emotional component, which confirms the right vector of our research. This problem becomes even more important when we understand that the specifics of the educational process of a higher military educational establishment are determined predominantly by an authoritarian (strictly regulated) system of educational process management, which is based on statutory relations, which influences the implementation of any type of activity of a future officer-bordergurd. In spite of the presence of scientific works in which the emotional sphere of the personality is investigated, it is necessary to pay attention to the lack of studies of the emotional competence of socionomic spheres professionals and psychological and pedagogical conditions of its development in the process of foreign language teaching at higher military educational institutions and, as as a result, to the absence of a consistent, thorough approach to managing this process.

${ }^{16}$ Bulakh I. S., Dolynska L. V. (2002) Psyhologichni aspekty mizhosobystisnoi vzaiemodii vykladachiv $i$ studenti: navch. metod. posib. [Psychological aspects of interpersonal interaction of teachers and students: methodical textbook]. - K.: NPU named after Drahomanov. [in Ukrainian].

${ }^{17}$ Patiushkin V. P. (1984) Funktsyi $i$ formy sotrudnichestva uchitelia $i$ uchashchihsia $v$ uchebnoi dieiatelnosti [Functions and forms of interaction of the teacher and students in learning activity]: PHD Thesis in Psychology. [in Russian].

${ }^{18}$ Bekh I. D. (1998) Osobystisno-zoriientovane vyhovannia: nauk. metod. posibnyk [Personality-oriented education: scient.- method. textbook]. - K.: IZMN. [in Ukrainian].

19 Postalovskyi I. (1999) Trenirovka intensivnogo slushania [Training of intensive listening]. - Odessa: Reclamservise. [in Russion]. 
Therefore, it is extremely important for the teacher at a military institution to acquire a high level of emotional competence to be able to properly organize and implement subject-subject interaction in order to provide effective foreign language teaching to cadets-bordergurds.

Our study takes into account the characteristics of educational groups of a higher military educational institution, which have not only common for any other study group social and psychological features, but also specific ones, which are caused by the tasks defined by the higher military educational institution, the nature of the cadets' daily activities. Cadets are not only to study, but also execute military service, fulfilling all elements of military service. Having examined its activity specificity, we find such features as the follows: uniformity of age structure of educational groups members, their merger into a single educational process; relative stability, duration and continuity of interaction and intensity of communication of all its members; relatively high level of self-government; the presence of sufficiently strict relations regulation and functional dependence of the group members determined by the system of subordination; observance of military discipline and order; uniformity in complex jointly coordinated activities etc.

Today, it should be understood that the teacher faces a challenge in organizing subject-subject interaction in foreign language classes, because it is necessary to take into account the emotional request of the entire study group and to establish a favorable psychological atmosphere. The difficulty is that today young people who entered the military institution are not only after secondary school education, but also those who have some experience of serving in the Joint Forces Operation zone in the east of Ukraine. This aspect leads to the search and development of new methods, approaches and algorithms for working in groups with different background cadets. And the task of the foreign language teacher in this case is to resort to such an organization of interpersonal interaction, which should unite the training group as a whole and actualize all possible levers of emotional influence for the development of motivation for mastering a foreign language and overcoming the psychological barriers that create paralyzing conditions in a joint foreign language activity.

In the conditions of higher military educational institutions, the emotional competence of the teacher, who can use his entire professional arsenal in creating a favorable psychological climate, plays a particularly important role. The teacher should not dominate the audience, but seek to engage the learning subjects with the communication process, enabling them to interact with others, creating the conditions for the development of their self-awareness and self-regulation. The role of the teacher as an interlocutor puts him on an equal footing with those who are being taught, which helps to eliminate the psychological barriers between them, eases the stress during 
the class, creates more free conditions for communication $^{20}$ (O. Hrynchyshyn, 2003, p. 137-138). In this context, the teacher's personality and his emotional competence play a crucial role in the teaching process. O. Fuhelo, examining the indicators of work satisfaction at the stage of professional formation of military personnel, found that the social and psychological climate of the military group largely depends on the commander of the unit. He argues that the major drawbacks of officers' training are their poor awareness of the problems of managing the spiritual processes, emotions and values of military units. The author argues that commanders who have subordinates do not always have the high level of skills to work with them. This leads to psychological discomfort for all participants in the service and education process. "When comparing the levels of cadets' service (training, studying) satisfaction, it was found that in those companies where the commander's style of work is based not on the humanity laws but only on giving orders, these levels were lower by 1.4-1.8 times» $^{21}$ (O. Fuhelo, 2004, p.87).

Foreign language, as a subject of teaching, reveals powerful resources for the development of professional competence of future military specialists. O. Volobuieva ${ }^{22}$ (O. Volobuieva, 2010, p.36) also emphasizes that "the peculiar psychological nature of a foreign language as an educational subject influences all the mental processes of the cadet: the peculiar features are characterized by the processes of feeling and perception; high foreign language memory requirements; plays a particularly complex and peculiar role in foreign language thinking; the feelings and emotions associated with learning a foreign language are quite peculiar; special requirements are placed by the teaching of a foreign language to the cadets and students' attention and will».

The professional personality formation is a complex process of interaction between intellectual and emotional development. Such components of the emotional sphere of personality as emotional stability,

${ }^{20}$ Hrynchyshyn O.M. (2003) Rozvytok motyvatsii ovolodinnia inizemnoiy movoiu v umovah vyshchogo viiskovogo navchalnogo zakladu [Motivation development of a foreign language learning in the conditions of a higger military educational institution]. PHD Thesis in Psychology : 19.00.09. - Khmelnytskyi: NADPSU Publishing. [in Ukrainian].

${ }^{21}$ Fuhelo O. M. (2004) Otsinka, kryterii ta pokaznyky zadovolenosti pratseiu na etapi profesiinogo stanovlennia viisovosluzhbovtsiv [Evaluation, criteria and indicators of work satisfaction at the stage of serviceman's professional formation]. Zbirnyk naukovyh prats № 26. Chastyna II. Collection of scientific works № 26. Part II. - Khmelnytskyi: Publ. NASBGSU. [in Ukrainian].

22 Volobuieva O. F. (2010) Psyhologichni zasady rozvytku profesiinyh inshomovnyh zdibnostei maibutnioho viiskovogo profesionala [Psychological principles of professional foreign languages abilities of future military professional]: diss. ...doctor of psychol. sciences; The G. S. Kostiuk Institute of Psychology NAPN of Ukraine. [in Ukrainian]. 
emotional self-regulation, emotional intelligence and emotional competence in whole, are not less important than the mental, social, intellectual spheres.

We consider the emotional competence of a foreign language teacher of a higher military educational institution as a component of professional competence and as a set of abilities and skills to achieve the ultimate goal in joint foreign language interaction with future military professionals taking into account the subject- subject interaction criteria in the condition of strict military subordinative structure. The teacher exhibits a high level of self-awareness, selfmanagement, social awareness, relationship management etc.

We found interesting for our study the workout of I. Matiikiv ${ }^{23}$ (I. Matiikiv, 2013, p. 146-147). The psychologist defines the emotional competence criteria of socionomic specialist which included: life position, level of subjective control, management of emotions (basic emotional competences), type of thinking (positive, negative), type of motivation, reflexive skills, self-esteem, communicative potential, type of behavior. These criteria and their indicators are the basis for developing the structure of emotional competence and levels of its formation. Having defined two levels (low and high), reflecting the qualitative structure of emotional competence formation process, the researcher attributes to them certain psychological characteristics (Fig. 1).

Selected emotional competence criteria by I. Matiikiv overlap with the criteria of subject-subject interaction, which we have studied in our research: the criterion of self-regulation, the criterion of social comfort, predictive criterion which reflect the attitude of subjects of education to the ability to change the level of self-identity in the process of interaction with teachers and create a desire to get engaged in the learning process and a willingness to change their minds, estimation, judgments, attitudes, and this is not accompanied by negative emotions etc. Such a comparison proves that the hypothesis of our study is valid and has grounds for further study ${ }^{24}$ (V. Hrishko-Dunaievska, 2011).

23 Matiikiv I. (2013) Emotsiina kompetentnist iak psyhologichnyi obiekt vyhovannia osobystosti maibutniogo fahivtsia profesii typu "liudyna-liudyna" [Emotional competence as psychological object of education of future specialist of "man-man" type profession]. Pedagogika i psyhologiia osvity. Pedagogy and psychology of Education. №2. Retrieved from: http://lib.iitta.gov.ua/6156/1/Pippo_2013_2_19.pdf [in Ukrainian].

${ }^{24}$ Hrishko-Dunaievska V. A., Volobuieva O.F. (2011) Kryterii efektyvnosti subiekt0subiektnoi vzaiemodii u navchalno0vyhovnomu protsesi pry vyvchenni inizemnoi movy u VVNZ: psyhologichnyi aspect [Criteria of subject-subject interaction effectiveness in educational process while learning a foreign language at a higher military educational institution: psychological aspect]. Visnyk Natsionalnogo universytetu oborony Ukrainy: zbirnyk. nauk. prats. za red. Stasiuka V. V. Heald of scient. works in red. Of Stasiuk V.V.- K.: NUOU. Issue. 6 (25). [in Ukrainian]. 
Criteria: life posture by Harris; level of subjective control (external and internal); time competence; managing emotions (basic emotional competencies); type of thinking; type of motivation; reflexive skills; self-esteem; communicative potential; type of behavior

\begin{tabular}{|l|}
\hline \multicolumn{1}{|c|}{ Low level } \\
\hline - irresponsibility for the events \\
of own life, which is perceived \\
as a consequence of external \\
factors; \\
- distortion of reality perception, \\
a focus on the past or the future; \\
-insufficient process of \\
observing emotions and \\
analyzing them; \\
- low behavior self-control; \\
- internal tension, lack of living \\
emotions;
\end{tabular}

- inability to use the techniques

of psychophysiological self-

regulation;

- uncontrollable outburst of emotions by the mechanism of conditioned reflex;

- the tendency to constantly pessimistic thinking, focusing on the problem, not the way to solve it;

- low tolerance to situations of failure;

- motivation to avoid failure instead of setting yourself up for success; - low level of self-knowledge skills development;

- avoidance of honest and open relations, which determines the formality of the relationship; - inattention to other people's emotional state; - misunderstanding of the importance of non-verbal communication component; - protective, rigid behavior

- a life-affirming attitude to oneself and own surroundings;

- responsibility for own emotions and life in general;

- the adequacy of the sense of reality and its objective perception;

- analysis and understanding of emotional experiences causes;

- management and control of the emotional experiences intensity;

- ability to motivate yourself and others;

-expression of emotions and feelings on verbal and nonverbal levels, use of other means of emotional expression adequate to the situation and social and cultural norms; - possession of techniques of psychophysiological selfregulation;

- the ability to choose from a wide range of possible emotional reactions at a particular moment one that will help to work and interact with people effectively; - optimistic thinking, developed sense of humor, cheerfulness, energy;

- self-confidence, especially in unfamiliar situations, in the face of uncertainty;

- achievement motivation, mobilization of forces and focus on goal achievement; striving for self-knowledge, development and self-improvement, own potential realization;

- adequate self-esteem;

- the ability to establish and maintain emotionally supportive and comfortable relationships;

- ability to identify (recognize, understand) the emotions of other people, to analyze the causes of their occurrence, - sympathize (empathy) and provide emotional support;

- ability to active listening, to constructive feedback;

- openness and tolerance to those views and opinions

that differ from the own ones;

- ability to be congruent; assertive behavior;

a wide range of emotional responses, the ability to change their plans when circumstances require

\section{Fig. 1. Psychological characteristics of levels of emotional competence} of the individual by I. Matiikiv

\section{Experimental study of foreign language teachers' emotional intelligence levels at the NASBGSU (N. Hall Emotional Intelligence Test)} Although researchers view the structure of emotional competence differently, they all emphasize that emotional competence is the individual's 
motivational and energy resource and it manifests itself as a factor and indicator of personality development, his or her psychological well-being and mental health.

For this reason, we have addressed the teachers of the English Language and Translation Departments (in number of 28 persons) of the National Academy of the State Borderguard Service of Ukraine named after B. Khmelnytsky (hereinafter - NADPSU) with the request to answer the N. Hall Emotional intelligence Test ${ }^{25}$ (D. Raihorodskyi, 2002). N. Hall's test for determining the level of emotional intelligence is based on a mixed model of emotional intelligence and constructed as a questionnaire that demonstrates the ability to understand the relationship represented in emotions and to manage the emotional sphere on the basis of decisions. This technique contains 30 statements. The test involves the evaluation of 5 components of emotional intelligence: emotional awareness, managing one's emotions, self-motivation, empathy, coaching others' emotions. The response scale is six-step type. The teachers were required to write a number to the right of each statement based on their stage of agreement with it: Disagree very much (-3 points); disagree moderately ( -2 points); disagree slightly ( -1 point); agree slightly $(+1$ point); agree moderately ( +2 points); agree very much $(+3$ points). The points are calculated with the help of a pre-prepared «key», the positive and negative answers are calculated. Score is determined by a custom table. The results determine the level of partial emotional intelligence according to the sign of the results, i.e. definite strength (high), needs some development (average), need substantial development (low) levels. The integrative level of emotional intelligence is determined separately, taking into account the dominant sign. The author identifies three levels of emotional intelligence on each of the scales: need substantial development level (7 and less), need substantial development level (8-13) and definite strength level (14 or more points).

The results of the study of the levels of partial emotional intelligence are graphically shown in Fig. 2-6.

${ }^{25}$ Raigorodskyi D. Ia. (2002) Prakticheskaia psihidiagnostika. Metodiki i testy: uchebnoie posobiie [Practical Psychodiagnostics. Methodics and tests. Textbook]. Samara: Publishing House BAHRAH-M. [in Russian]. 


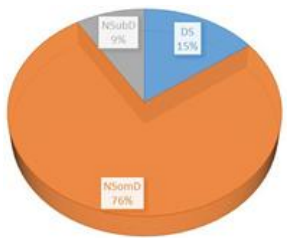

Fig. 2 Coaching others'emotions

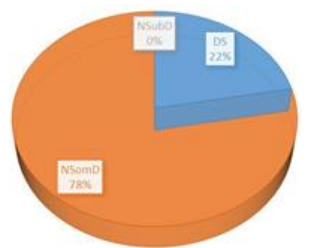

Fig 3. Emotional awareness

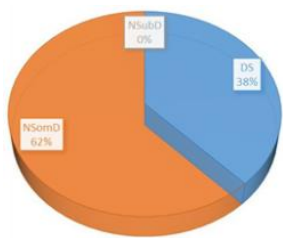

Fig 4. Managing one's emotions

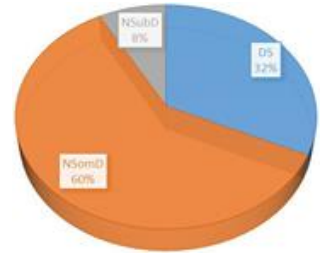

Fig. 5 Self-motivation

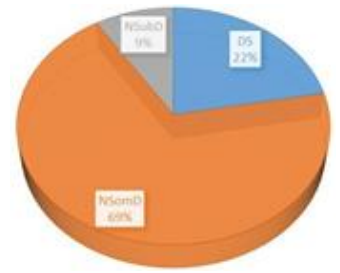

Fig. 6 Empathy

Figures 2-6 show that in the scales of «emotional awareness» and «managing one's emotions» foreign language teachers are above average (78\% and 62\% respectively), but what is important that these two scales did not reveal low levels of these abilities; while other scales namely «empathy» (high-22\%, average-69\%, low 9\%), "self-motivation» (high-32\%, average$60 \%$, low- $8 \%$ ), «coaching others' emotions» (high-15\%, average-76\%, low $9 \%$ ) are in average level dominantly, but testing has shown a presence of low percentage of these emotional intelligence abilities.

Thus, these data indicate that there are problematic aspects that need further development. On an empathy testing scale, we can state that foreign language teachers are able to empathize with another person's emotional state, to support them, understand and accept the feelings and emotions of others, to put themselves in other's place in a variety of situations, and can also provide an emotional assessment actions and to teach cadets, that is, to develop the capacity for empathy - to accept those feelings that someone else is experiencing, as if they were their own. But the low percentage indicates the possibility of starting conflict and difficulties in finding compromise solutions in non-standard situations.

The results of testing on "coaching others' emotions» scale appeared to be a problematic aspect, which is especially important for foreign language teachers of military higher education in iteraction with cadets. Psychology of military discipline and subordination itself teaches to suppress the cadets' true feelings and emotions, but it is essential to create a favorable emotional 
climate in the study group for introduction into a foreign language environment, and the teacher is to see, recognize and coach the cadets' true emotions. Then it is possible to solve the problem at the stage of its birth, to eliminate psychological paralyzing barriers that neutralize and inhibit all psychological principles of creating conditions for mastering a foreign language.

The results on the scale of «self-motivation» show that foreign language teachers are positively motivated professionals, show a willingness to successfully pursue a professional activity, produce new, original ideas, stay initiative, carry out a creative search. But in order to reorient an individual's behavior to his/her internal reserves and motivated efforts, it is necessary to synthesize into a single system the best methods, modern techniques, conduct a self-work, promote the opportunities for enhancing one's own activity for professional and personal success.

The high and average percentages of the «managing one's emotions» and «emotional awareness» scales demonstrate a sufficient level of tested competence. The teachers are aware of their inner state. In managing their emotions, they have sufficient emotional flexibility and skillful management of their emotions, they are capable of congruence and self-competence; have assertive behavior; have a wide range of emotional responses, the ability to change their plans when circumstances require, and to interact with future border guards in joint foreign language activities.

The results of the study of the levels of development of integrative emotional intelligence of foreign language teachers are shown in Figure 7.

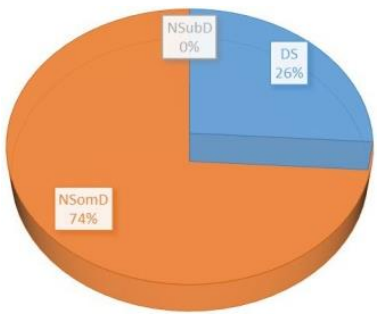

Fig. 7

Analyzing the test results of the levels of development of the integrative emotional intelligence of foreign language teachers of NADPSU, we can say that the average level $(74 \%)$ is dominant here and the high level have a significant percentage $(26 \%)$. The lack of low level of development of emotional intelligence demonstrates that the foreign language teachers of NASBGSU provide a psychological basis for the development of positive, 
partnership, equal relations, which create the conditions for the implementation and organization of subject-subject interaction in the joint foreign-language activity of members of the training group, mutual cognitive emotional reflection, anticipation, etc. The ability to take responsibility and control one's own actions is an indicator of the emotional and social maturity of a professional. An emotionally competent teacher is able to create a favorable psychological microclimate to eliminate the psychological barriers that facilitate the tensions of the military atmosphere of strict subordination that is inherent in all military structures. We can state the emotional stability of the teacher and his/her affiliation with the subject, in particular, the benefits of indirect managerial influence on the study group as a whole and on each cadet; the teacher's consideration of communication partners (cadets) expectations for professional activity; a high degree of positive motivation of the learning activities of the subjects of study, their interest in learning a foreign language for further effective professional activity at the border under special conditions; direct interaction between the subjects of the educational process and mutual satisfaction with productive foreign language cooperation.

\section{CONCLUSIONS}

To sum up, theoretical analyses of the conceptual approaches to the notion of emotional intelligence in contemporary psychology have been conducted to define that emotional intelligence is considered as a set of diverse abilities (cognitive, emotional, adaptive, social) that provide the opportunity to act successfully in any situation. Its structure includes selfunderstanding (awareness of own emotions, self-confidence, selfactualization); communicative potential (empathy, social responsibility); adaptive abilities (ability to overcome difficulties, emotional lability); antistress potential (self-control); optimism.

However, the complex profession of the teacher requires constant selfimprovement, and as it has been confirmed in our study, the emotional competence of the teacher emerges as a complete and progressive development of the emotional sphere of the individual and represents a set of knowledge, skills and abilities that allow to act adequately on the basis of the profession of the whole information. Emotional competence enriches the experience of the individual, provides a quick analysis of emotional situations. That is why emotional competence can and should act as one of the basic aspects of forming a foreign language teacher's personality. But the identified problematic aspects of the study of the levels of partial emotional intelligence of foreign language teachers in the scales of «Empathy» and «Coaching others' emotions» and "Self-Motivation" require further substantial development in these areas, with the aim of establishing honest 
and frank relationships, which weakens the formality of the relationship of subordination and status coordination; increases the level of attention to the emotional state of others, understanding the importance of the non-verbal component of communication; changes protective, rigid behavior to assertive one, displaying flexibility in managing emotional reactions, thoughts, and behaviors according to communicative situations and conditions that change in joint foreign language learning activity etc.

Perspective way of further research is development and implementation of efficient methods and techniques of improving emotional competence components, namely to work out a social and psychological training of emotional competence for the teachers of foreign language at the higher military educational instituon.

\section{SUMMARY}

The article deals with revealing the role of the teacher's emotional competence in subject-subject interaction in foreign language learning process taking into account the features of the higher military educational istitution. The emotional competence of a foreign language teacher of a higher military educational institution is considered as a component of professional competence and as a set of abilities and skills to achieve the ultimate goal in joint foreign language interaction with future military professionals taking into account the subject- subject interaction criteria in the condition of strict military subordinative structure.

The emotional competence criteria have been defined: life position, level of subjective control, management of emotions (basic emotional competences), type of thinking (positive, negative), type of motivation, reflexive skills, self-esteem, communicative potential, type of behavior. Experimental study (N. Hall Emotional Intelligence Test) of the foreign language teachers' emotional intelligence levels at the NASBGSU has been conducted and some problematic aspects have been revealed: three scales («empathy» (high-22\%, average-69\%, low 9\%), «self-motivation» (high$32 \%$, average-60\%, low-8\%), «coaching others' emotions» (high-15\%, average-76\%, low 9\%) are dominantly in average level, but testing has shown a presence of low percentage of these emotional intelligence abilities and they need further substantial development and working out.

\section{REFERENCES}

1. Batrakova S. N. (1986) Osnovy professional-pedagogicheskogo obshchenia [Principles of pedagogical communication] - Yaroslavl: Yar. state. university. [in Russian]. 
2. Bekh I. D. (1998) Osobystisno-zoriientovane vyhovannia: nauk. metod. posibnyk [Personality-oriented education: scient. - method. Textbook]. - K.: IZMN. [in Ukrainian].

3. Bulakh I. S., Dolynska L. V. (2002) Psyhologichni aspekty mizhosobystisnoi vzaiemodii vykladachiv $i$ studentiv: navch. metod. posib. [Psychological aspects of interpersonal interaction of teachers and students: methodical textbook]. - K.: NPU named after Drahomanov. [in Ukrainian].

4. Dubovyi K. V. (2012) Psyhologichni umovu rozvytku komunikatyvnyh $i$ kognityvnyh komponentiv inshomovnyh zdibnostei studentiv [Psychological conditions of development of students' communicative and cognitive foreign language abilities] PHD Thesis in "Pedagogic and Age psychology": specialty 19.00.07. - Khmelnytskyi: NASBGSU publ. [in Ukrainian].

5. Free Encyclopedia (2019). Retrieved from: https://uk.wikipedia.org/ wiki/Емоційний_інтелект [in Ukrainian].

6. Fuhelo O. M. (2004) Otsinka, kryterii ta pokaznyky zadovolenosti pratseiu na etapi profesiinogo stanovlennia viisovosluzhbovtsiv [Evaluation, criteria and indicators of work satisfaction at the stage of serviceman's professional formation]. Zbirnyk naukovyh prats № 26. Chastyna II. Collection of scientific works № 26. Part II. - Khmelnytskyi: Publ. NASBGSU. [in Ukrainian].

7. Hrishko-Dunaievska V. A. (2017) Osobluvosti subiekt-subiektnoi vzaiemodii $v$ protsesi vyvchennia inozemnoi movy $u$ vyshchyh viiskovyh navchalnyh zakladah [Peculiariyies of subject-subjekt interaction in the foreign language learning process at higher military educational institution] (PHD Thesis in "Pedagogic and Age psychology": specialty 19.00.07). Khmelnytskyi. (NASBSU) [in Ukrainian].

8. Hrishko-Dunaievska V. A., Volobuieva O.F. (2011) Kryterii efektyvnosti subiektOsubiektnoi vzaiemodii u navchalno0vyhovnomu protsesi pry vyvchenni inizemnoi movy $u$ VVNZ: psyhologichnyi aspect [Criteria of subject-subject interaction effectiveness in educational process while learning a foreign language at a higher military educational institution: psychological aspect]. Visnyk Natsionalnogo universytetu oborony Ukrainy: zbirnyk. nauk. prats. za red. Stasiuka $V$. V. Heald of scient. works in red. Of Stasiuk V.V.- K.: NUOU. - Issue. 6 (25). [in Ukrainian].

9. Hrishko-Dunaievska V. A., Volobuieva O.F. (2011) Kryterii efektyvnosti subiektOsubiektnoi vzaiemodii u navchalno0vyhovnomu protsesi pry vyvchenni inizemnoi movy u VVNZ: psyhologichnyi aspect [Criteria of subject-subject interaction effectiveness in educational process while learning a foreign language at a higher military educational institution: psychological aspect]. Visnyk Natsionalnogo universytetu oborony Ukrainy: 
zbirnyk. nauk. prats. za red. Stasiuka $V$. V. Herald of scient. works in red. Of Stasiuk V.V.- K.: NUOU. - Issue. 6 (25). [in Ukrainian].

10. Hrynchyshyn O.M. (2003) Rozvytok motyvatsii ovolodinnia inizemnoiy movoiu $v$ umovah vyshchogo viiskovogo navchalnogo zakladu [Motivation development of a foreign language learning in the conditions of a higger military educational institution]. PHD Thesis in Psychology: 19.00.09. - Khmelnytskyi: NADPSU Publishing. [in Ukrainian].

11. Izard K. (1980) Emocii cheloveka [Man's Emotions]. M. - 440 p. [in Russian]

12. Komar T.V. (2014) Sotsialno-psyhologichnyi prostir yak chynnyk profesiinoii zrilosti osobystosti [Social and psychological space as a factor of personality professional maturity] [Електронний pecypc] Visnyk Natsionalnoi akademii Derzhavnoi prukordonnoi sluzhby Ukrainy Scientific works collection of National academy of the State Border Guard Service of Ukraine- Issue 2. - Retrieved from: http://nbuv.gov.ua/UJRN/Vnadps_2014_2_17. [in Ukrainian].

13. Lazurenko O.O. (1997) Emotsii $i$ yikh znachennia $v$ zhyttiediialnosti liudyny [Emotins and their meaning in person's life activity]. Kyiv. [in Ukrainian].

14. Leontiev A. N. (2001) Dieiatelnost. Soznanie. Lichnost. [Activity. Consiuosness. Personality] - M. [in Russian].

15. Lomov B. F. (1981) Problema obshcheniia v psihologii [Problem of communication in psychology] - M.: Science. [in Russian].

16. Matiikiv I. (2013) Emotsiina kompetentnist iak psyhologichnyi obiekt vyhovannia osobystosti maibutniogo fahivtsia profesii typu "liudynaliudyna" [Emotional competence as psychological object of education of future specialist of "man-man" type profession]. Pedagogika i psyhologiia osvity. Pedagogy and psychology of Education. № 2. Retrieved from: http://lib.iitta.gov.ua/6156/1/Pippo_2013_2_19.pdf [in Ukrainian].

17. Nosenko E. L., Kovryga N. V. (2000) "Emotsiina rozumnist" iak determinanta uspishnoi zhyttiediialnosti liudyny $i$ shliahy iioperatsionalizatsii [Emotional reasonability as a factor of successfulperson's life activity and the ways of its operanalization]. Visnyk Dnipropetrovskogo Universytetu [Herald of the Dnipropetrovsk University. - Pedagogy and Psychology. - Issue. 6.

18. Nosenko E. L., Kovryga N.V. (2006) Emotsiinyi intellect: kontseptualizatsia fenomeny, osnovni funktsii: monografia. [Emotional intelligence: phenomenon conceptualization, main functions: monograph]. Vyshcha shkola. Higher School. [in Ukrainian].

19. Patiushkin V. P. (1984) Funktsyi i formy sotrudnichestva uchitelia $i$ uchashchihsia $v$ uchebnoi dieiatelnosti [Functions and forms of interaction 
of the teacher and students in learning activity]: PHD Thesis in Psychology. [in Russian]

20. Postalovskyi I. (1999) Trenirovka intensivnogo slushania [Training of intensive listening]. - Odessa: Reclamservise. [in Russion].

21. Shcherban T. D. (2004) Psyhologia navchalnogo spilkuvannia: monografia [Psychology of study communication]: monograph. - K.: Millenium. [in Ukrainian].

22. Sukhomlynskyi V. A. (1974) Serdtse otdaiu dietiam [Give my heart to the children]. - 5-th issue. - K.: Radianska shkola. Soviet Shcool. [in Russian].

23. Vlasova O. I. (2005) Psyhologia sotsialnyh zddibnostei: structura, dynamika, chynnyky rozvytky: monografia [Psychology of social abilities: structure, dynamics, development factor: Monograph]. K.: Vydavnychopoligrafichnyi tsentr "Kyivskyi Universytet". Publishing center "Kyiv University". [in Ukrainian].

24. Volobuieva O. F. (2010) Psyhologichni zasady rozvytku profesiinyh inshomovnyh zdibnostei maibutnioho viiskovogo profesionala [Psychological principles of professional foreign languages abilities of future military professional]: diss. of ...doctor of psychol. sciences; The G. S. Kostiuk Institute of Psychology NAPN of Ukraine. [in Ukrainian].

25. Yakovleva E. L. (1997) Emotsionalnyie mehanismy lichnosnogo $i$ tvorcheskogo razvitia [Emotional mechanisms of personal and creative development]. Voprosy psihologii. Psychology Issues. - No 4. [in Russian].

Information about the author: Valentyna Hrishko-Dunaievska, Candidate of Psychological Science, Senior Instructor of the English Language Department, NASBGS of Ukraine, 46 Shevchenko str., Khmelnytskyi, Ukraine, 29000 ORCID ID: orcid.org/ 0000-0001-5365-0355 valentine999@ukr.n 